\title{
Adsorptive removal of cationic dye from aqueous solution using chemically modified African Border Tree (Newbouldia laevis) bark
}

\section{*11AJAELU, C JOHN ; ${ }^{1}$ NWOSU,VIVIAN; ${ }^{1}$ IBIRONKE, LARA; ${ }^{1}$ ADELEYE, ADEBAYO}

\author{
${ }^{1}$ Department of Chemistry and Industrial Chemistry, Bowen University, Iwo, Nigeria \\ ${ }^{*}$ Corresponding Author Address: ajaelujohn46@gmail.com
}

\begin{abstract}
This study investigated the biosorption efficiency of sodium hydroxide modified African Border tree (SMABT) bark powder on Safranin O, a cationic dye. The SMABT was characterized by Fourier Transform Infrared Spectroscopy (FTIR). As the initial dye concentration increased, the amount of Safranin O removed increased. The kinetic studies were described by pseudo first order and pseudo second order. The pseudo second order fitted very well into the kinetic experimental data. Freundlich, Langmuir, Temkin and Dubinin-Radushkevich (D-R) models were employed to describe the adsorption of Safranin O to SMABT and also to evaluate the isotherm constants. Langmuir model was the best of the four to excellently fit into the experimental data. The maximum uptake capacity of SMABT for Safranin O dye was $90.9 \mathrm{mg} / \mathrm{g}$.

DOI: https://dx.doi.org/10.4314/jasem.v21i7.18
\end{abstract}

Copyright @ 2017 Ajaelu et al. This is an open access article distributed under the Creative Commons Attribution Non-Commercial License (CC-BY-NC), which permits unrestricted use, distribution, and reproduction in any medium, provided the original work is properly cited.

Received 15 October 2017, received in revised form 03 December 2017, accepted 31 December 2017.

Keywords: African Border Tree, kinetics, equilibrium, adsorption, Safranin O

Rapid industrialization has increase the presence of dyes in the environment. These dyes are produced or used by industries such as food, pharmaceutical, cosmetic, dyestuffs, textile, paper and plastics. The dye effluents from these industries result in coloured wastewater. It was found that colour was the first contaminant to be recognized in wastewater (Banat et al., 1996). Many of the dyes are toxic and carcinogenic and these pose a serious hazard to aquatic living organisms (Vijayaraghavan and Yun 2008). Dyes also interfere with the transmission of light and upset the biological metabolism processes which cause the destruction of aquatic communities present in ecosystem (Walsh et al., 1980). In addition, dyes have a tendency to sequester metal and may cause microtoxicity to fish and other organisms (Walsh et al., 1980).

Diverse but expensive methods which have been used to remove dyes include flocculation, oxidation, irradiation, electrolysis, precipitation, ozonation, ion exchange, membrane filtration, electrochemical destruction and activated carbon. Among the various methods of dye removal, the use of agricultural materials, also known as biosorption, has been proven to be superior since it is more cost effective, efficient, readily available, generates no sludge or by products. Some of the adsorbents that have been used to remove dyes include Cassia siamea (Ajaelu et al., 2011), Mangifera indica (Ajaelu et al. 2015), watermelon (Ahmad et al., 2015), Senna alata (Ajaelu et al. 2017), Moringa oleifera (Bello et al.
2017), Walnut shell (Ojo et al. 2017), Corn cob (Ojedokun and Bello 2017). Safranin-O, also known as basic red 2, is a basic dye. Basically, Safranins are the azonium compounds of symmetrical3,7-Diamino2,8-dimethyl-5-phenylphenazin-5-ium chloride. Safranin-O is widely used in textile industry and it creates hazard due to its disposal into water bodies (Daru, 2005). African border tree is also known as Newbouldia laevis with lush, tropical looking leaves and pink flower. It belongs to the shrub category and the family Bignoniaceae. In this study chemically modified African Border Tree (SMABT) was used to remove Safranin O, a cationic basic dye, from simulated waste water.

\section{MATERIALS AND METHODS}

The African Border Tree bark was obtained from Iwo town in Osun State. The Safranin O, sodium chloride, sodium hydroxide and hydrochloric acid used were of analytical grade. Distilled water was used throughout this study. Fig 1 shows the chemical structure of Safranin O.

The African Border Tree bark was washed to remove sand and air dried after which it was oven-dried at $105^{\circ} \mathrm{C}$ overnight. It was then ground and screened through a $1 \mathrm{~mm}$ sieve to obtain the geometric size. 25 $\mathrm{g}$ of the African Border Tree was mixed with $0.5 \mathrm{M}$ $\mathrm{NaOH}$ in the ratio of 1:20 under agitation in a Stuart Orbital Electrical Shaker for $1 \mathrm{~h}$. The modified sample was then washed with distilled water and dried at $105^{\circ} \mathrm{C}$. The modified sample was called

**Corresponding Author Address: ajaelujohn46@gmail.com 
sodium hydroxide modified African Border Tree (SMABT) and stored in an air tight plastic bag.

Instrumental analysis of SMABT: The functional groups on the surfaces of SMABT was analyzed by Fourier Transform Infrared Spectrophotometer, Agilent Technologies Cary 630 FTIR spectrometer. A sample press, which is part of the ATR interface, was used to ensure that the ground SMABT was in good contact with the sensor surface. Scanning range in the region of $4,000-650 \mathrm{~cm}^{-1}$ at $4 \mathrm{~cm}^{-1}$ resolution.

Batch Adsorption studies: Adsorption studies were carried out by determining the solution $\mathrm{pH}$, initial Safranin $\mathrm{O}$ concentration, mass of adsorbent and contact time. The solution $\mathrm{pH}$ was adjusted by adding either $0.1 \mathrm{M} \mathrm{NaOH}$ or $0.1 \mathrm{M} \mathrm{HCl}$ solutions before adsorption experiment. Batched adsorption studies were carried out in a $250 \mathrm{~mL}$ standard flask using 20 $\mathrm{mL}$ Safranin $\mathrm{O}$ solution, with required dosage of adsorbent at $25{ }^{\circ} \mathrm{C}$. The flasks were placed on an electric shaker running at $300 \mathrm{rpm}$ until adsorption equilibrium was obtained. The concentration of Safranin O was determined using a Jenway_6305 ultraviolet spectrophotometer. All the experiments were performed in duplicate and the mean value was taken for later calculation.

Adsorption capacity of the SMABT was calculated using the following expression:

$$
\begin{aligned}
& q_{e}=\frac{\left(C_{o}-C_{e}\right) V}{w} \\
& \% \text { sorption capacity }=\frac{\left(C_{o}-C_{e}\right)}{C_{o}} \times 100
\end{aligned}
$$

Where $\mathrm{q}_{\mathrm{e}}(\mathrm{mg} / \mathrm{g})$ represents the amount of adsorbed Safranin O per amount of adsorbent, $\mathrm{C}_{\mathrm{e}}(\mathrm{mg} / \mathrm{L})$ is the equilibrium concentration of Safranin $\mathrm{O}$ in solution while $\mathrm{C}_{\mathrm{o}}(\mathrm{mg} / \mathrm{L})$ is the initial concentration of Safranin $\mathrm{O}$ in solution; $\mathrm{V}$ is the volume of the solution, $\mathrm{L}$; $\mathrm{m}$ is the mass $(\mathrm{g})$ of the SMABT.

Determination of pH point of zero charge: $10 \mathrm{ml}$ of already prepared $0.5 \mathrm{M} \mathrm{NaCl}$ was poured into eleven $250 \mathrm{ml}$ beakers each and the $\mathrm{pH}$ was conditioned to different $\mathrm{pH}$ ranging from 2 to 12 by adding drops of $\mathrm{NaOH}$ (to increase) or $\mathrm{HCl}$ (to decrease). $0.1 \mathrm{~g}$ of the SMABT was then poured into each of the $\mathrm{pH}$ conditioned $\mathrm{NaCl}$ solutions. The beakers were covered and kept for $24 \mathrm{hrs}$ after which their $\mathrm{pHs}$ were taken and recorded.

\section{RESULTS AND DISCUSSION}

Characterization of SMABT: FTIR spectrum (Fig.2) of SMABT after adsorbing Safranin $\mathrm{O}$ dye indicated that there are existences of some functional groups responsible for adsorption. A strong and broad band appeared at $3338 \mathrm{~cm}^{-1}$ and is attributed to the $\mathrm{OH}$ stretching vibration. The absorption band at $2898 \mathrm{~cm}^{-}$ ${ }^{1}$ was attributed to $\mathrm{C}-\mathrm{H}$ stretching vibration of alkane. The absorption value at $1593 \mathrm{~cm}^{-1}$ was assigned to antisymmetric stretching of COO- group. The vibrational absorption band at 1420 and $1459 \mathrm{~cm}^{-1}$ were both assigned to the $\mathrm{OH}$ bending. This indicates that adsorption occurred through the interaction of the cationic dye (Safranin O) with the $\mathrm{OH}$ and $\mathrm{COO}^{-}$functional groups on the surface of SMABT.

pH point of zero charge: The $\mathrm{pH}$ point of zero charge ( $\mathrm{pH}$ PZC $)$ of SMABT was obtained and the result is presented in Figure 2. The SMABT $\mathrm{pH}_{\mathrm{PZC}}$ obtained was 8.0. Anion adsorption is favoured at $\mathrm{pH}$ values lower than the $\mathrm{pH}_{\mathrm{PZC}}$ while cation adsorption is favoured by $\mathrm{pH}$ values higher than the $\mathrm{pH}_{\mathrm{PZC}}$ (Farahani et al. 2011).

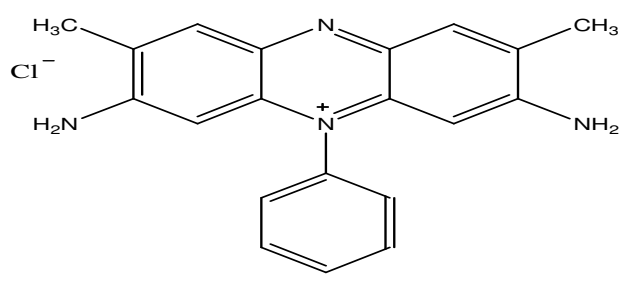

Fig. 1 Chemical Structure of Safranin O

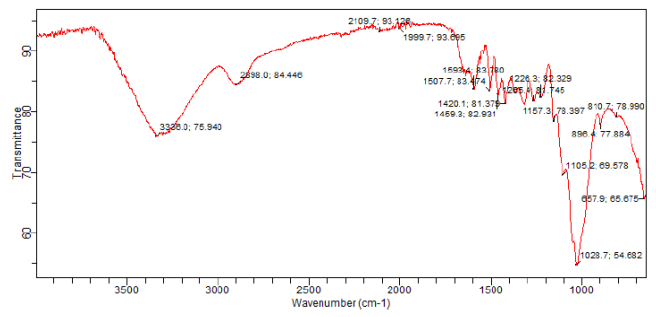

Fig. 2 FTIR of sodium hydroxide modified African Border Tree (SMABT)

Effect of $p H$ : The concentration of ions is considered as one of the vital parameters that influences the adsorption of dyes in aqueous solution. The percentage adsorption capacity of SMABT for Safranin $\mathrm{O}$ decreased gradually with increase in the $\mathrm{pH}$ from 2 to 12 as shown in Fig. 3. Similar result was obtained by Bello et al., (2017). The difference in the adsorption capacity as the $\mathrm{pH}$ increases may be due to the formation of different ionic species and surface charges. Fig. 4 shows the effect of $\mathrm{pH}$ point of zero charge on SMABT. The pHpzc obtained for SMABT was 8 . When the ${ }_{\mathrm{pHPZC}}$ is higher than the $\mathrm{pH}$ value, the Safranin O dye is of monomeric molecular and cationic forms (Deshpande et al., 2002). Thus the dye can easily access the adsorbent pore structure. When the $\mathrm{pH}_{\mathrm{PZC}}$ is lower than the $\mathrm{pH}$ value, there is 
the existence of zwitterion form of Safranin O dyes in the solution mixture. This form leads to the dimerization of the Safranin O dye molecules. These Safranin O (dimerized) molecules are unable to access the pores of the adsorbent because of their size, thus resulting in the decrease in the adsorption capacity as the $\mathrm{pH}$ increases. Ghanadzadeh et al. (2002) obtained similar result on the aggregation of rhodamin B dye on microporous solid host.

Effect of mass of biomass: The mass of biomass plays a vital role in the adsorption of dyes. Fig. 5 shows the graph of $\mathrm{q}_{\mathrm{e}}$ against mass of biomass. At higher SMABT to Safranin O concentration ratio, the sorption of the dye is higher. When the SMABT to Safranin O concentration ratio is lower, there is slow superficial sorption onto the adsorbent surface which is as a result of higher concentration of solute (Safranin O) remaining in solution. In addition, a specific amount of SMABT adsorbent can only adsorb a specific amount of Safranin O. The decrease in the amount of Safranin O adsorbed at the SMABT surface with increase in adsorbent dose is due to the concentration gradient or split in the flux between Safranin O dye concentration in the solution and the Safranin O concentration on the surface of SMABT. Therefore, the amount of Safranin O dye adsorbed onto unit mass of adsorbent (SMABT) decreased with increasing adsorbent weight, thus causing a reduction in amount of dye adsorbed $\left(q_{e}\right)$ as the mass of adsorbent increases. Zafar et al., (2006) obtained similar results.

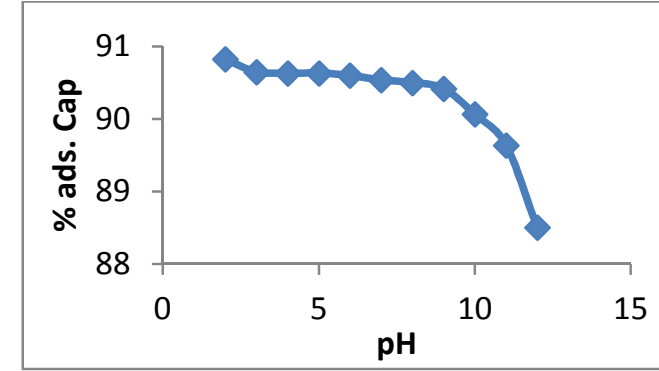

Fig. 3 The effect of $\mathrm{pH}$ on the adsorption of Safranin O on SMABT

Effect of initial dye concentration: Initial concentration of dyes affects its adsorption unto an adsorbent. At the early stage, the surface of the SMABT is devoid of Safranin O. Then the amount of Safranin $O$ begins to increase on the surface of the SMABT. Desorption of Safranin O also occurs until equilibrium is attained when the rate of adsorption equals the rate of desorption of Safranin O. In Fig. 6 it can be seen that the adsorption of Safranin O unto SMABT increases with increase in the initial concentration of the dye. At $20 \mathrm{mg} / \mathrm{L}$ the adsorption capacity was $3.93 \mathrm{mg} / \mathrm{L}$ while at $120 \mathrm{mg} / \mathrm{L}$ it was $22.1 \mathrm{mg} / \mathrm{L}$.

Adsorption kinetic studies: Kinetics studies of adsorption is very vital for it makes available valuable information on dye adsorption mechanism

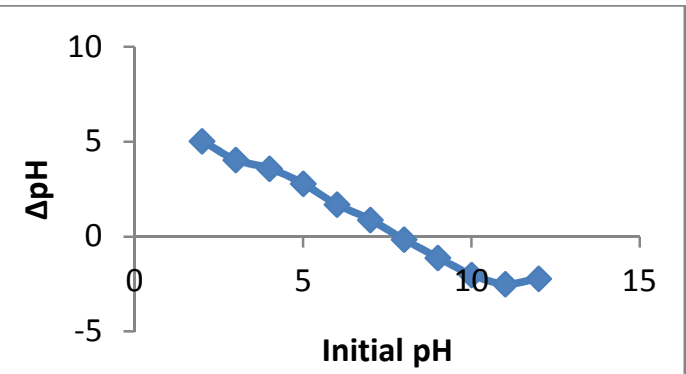

Fig. 4 The effect of $\mathrm{pH}$ point of zero charge on the adsorption of Safranin O on SMABT

of reaction. To determine the kinetics of the adsorption of Safranin O on SMABT, two kinetic models, Langergren first-order and pseudo- second order, were employed. The Langergren pseudo-first order equation is given below:

$$
\log \left(q_{e}-q\right)=\log q_{e}-\frac{k_{1}}{2.303} t
$$

Where $\mathrm{q}_{\mathrm{e}}(\mathrm{mg} / \mathrm{g})$ and $\mathrm{q}(\mathrm{mg} / \mathrm{g})$ are the biosorption capacities of the biosorbent at equilibrium and at any time $\mathrm{t}$, respectively; $\mathrm{k}_{1}$ is the langergren rate constant of the pseudo- first order biosorption. The plots of $\log \left(\mathrm{q}_{\mathrm{e}}-\mathrm{q}\right)$ versus $\mathrm{t}$ (min) for different Safranin $\mathrm{O}$ concentrations give straight lines (Figure not shown). From the plots, $\mathrm{k}_{1}$ and $\mathrm{q}_{\mathrm{e}}$ are determined from the slope and intercept respectively as shown in Table 1 .

\begin{tabular}{|c|c|c|c|c|c|c|}
\hline Parameters & $20 \mathrm{mg} / \mathrm{L}$ & $\begin{array}{l}40 \mathrm{mg} / \mathrm{L} \\
\text { Pseudo-first order }\end{array}$ & $60 \mathrm{mg} / \mathrm{L}$ & $80 \mathrm{mg} / \mathrm{L}$ & $100 \mathrm{mg} / \mathrm{L}$ & $120 \mathrm{mg} / \mathrm{L}$ \\
\hline $\mathrm{q}_{\mathrm{e}(\exp )}$ & 23.5 & 36.6 & 58.7 & 78.4 & 96.9 & 116 \\
\hline $\mathrm{q}_{\mathrm{e}(\mathrm{ealc})}$ & 13.2 & 11.4 & 7.44 & 14.5 & 21.6 & 9.95 \\
\hline $\mathrm{k}_{1} \times 10^{-3}\left(\mathrm{~min}^{-1}\right)$ & 0 & 2.0 & 0 & 2.0 & 4.0 & 0.01 \\
\hline SSE & 6.88 & $\begin{array}{l}19.3 \\
\text { Pseudo-second order }\end{array}$ & 36.3 & 45.2 & 53.3 & 75.0 \\
\hline $\mathrm{q}_{\mathrm{e}(\mathrm{calc})}$ & 23.5 & 38.6 & 58.7 & 76.9 & 100 & 111 \\
\hline $\mathrm{k}_{2} \times 10^{-4}\left(\mathrm{gmg}^{-1} \mathrm{~min}\right)$ & 2.07 & 0.82 & 4.0 & 0.13 & 0.03 & 0.05 \\
\hline $\mathrm{R}^{2}$ & 1 & $\begin{array}{l}0.02 \\
1\end{array}$ & 0.999 & 1 & 1 & 1 \\
\hline SSE & 0.20 & 0.13 & 0.06 & 1.04 & 2.18 & 3.54 \\
\hline
\end{tabular}


The linearized form of the pseudo-second order kinetic

Model is expressed as

$$
\frac{t}{q_{t}}=\frac{1}{k_{2} q_{e}{ }^{2}}+\frac{1}{q_{t}} t
$$

The plot of t/qt against $\mathrm{t}(\mathrm{s})$ as reflected in Fig. 7 shows that pseudo second order model is a better model for describing the adsorption kinetics of Safranin O on SMABT because it has high $\mathrm{R}^{2}$ values $\left(R^{2} \geq 0.999\right)$ and its qcalc are very close to that of the $\mathrm{q}_{\mathrm{exp}}$ as compared to that of pseudo first order model.

Adsorption Isotherm: Four isotherms, namely Freundlich, Langmuir, Temkin and DubininRadushkevich isotherms were employed to illustrate the observed experimental adsorption equilibrium data. The isotherms are stated below:

The Freundlich isotherm: The Freundlich equation is an empirical equation applied to describe heterogeneous systems. It is represented as

$$
\log q_{e}=\log k_{F}+\frac{1}{n} \log C_{e}
$$

Where $\mathrm{k}_{\mathrm{F}}\left(\mathrm{Lg}^{-1}\right)$ is associated with the adsorption capacity. Freundlich isotherm is shown in Figure 8 while the results are reported in Table 2. The $\mathrm{R}^{2}$ value of Freundlich isotherm is lower than that of Langmuir but higher than that of Temkin and D-R. The value $n$ gives an indication of the favourability of the adsorption process. When the value of $n$ is less than 1 the adsorption is said to be unfavourable, but if it is greater than 1 it is favorable (Xiong et al. 2010). The value of $n$ obtained in this study is greater than 1 which indicates that the adsorption process is favorable.

The Langmuir isotherm model: The Langmuir isotherm model for monolayer adsorption has gained wide application to dye sorption process. It is applicable to homogeneous systems where there is no interaction between the adsorbate molecules (Foletto

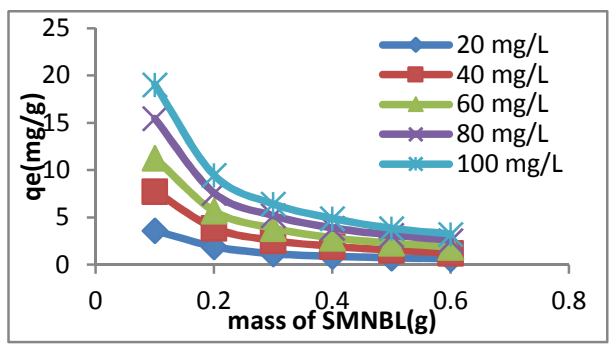

Fig. 5 Effect of mass of modified African Border Tree (SMABT) on the adsorption of Safranin O et al. 2011). The linear form of the equation is $\frac{C_{e}}{q_{e}}=\frac{1}{A_{o} b}+\frac{C_{e}}{A_{o}}$

Where $\mathrm{A}_{0}$ is the Langmuir maximum adsorption capacity $(\mathrm{mg} / \mathrm{g})$ and $\mathrm{b}$ is the Langmuir constant related to the binding site affinity and the adsorption energy in $\mathrm{Lmol}^{-1}, \mathrm{q}_{\mathrm{e}}$, is the adsorption capacity at equilibrium $(\mathrm{mg} / \mathrm{g})$ and $\mathrm{C}_{\mathrm{e}}$ is the equilibrium concentration of Safranin O $(\mathrm{mg} / \mathrm{L})$ in solution. From Table 2, the maximum adsorption capacity for the adsorption of Safranin O unto SMABT is $90.9 \mathrm{mg} / \mathrm{L}$. Langmuir isotherm is shown in Fig. 9. The correlation factor of Langmuir isotherm showed that it gives a very good fit and it is the best among the four isotherms for describing the adsorption of Safranin O on SMABT. A dimensionless equilibrium parameter, $\mathrm{E}_{\mathrm{L}}$, is one of the vital characteristics of Langmuir equation. It is expressed as

$E_{L}=\frac{1}{\left(1+a C_{o}\right)}$

Where $\mathrm{a}$ is the Langmuir equilibrium constant in $\mathrm{Lmol}^{-1}$ and $\mathrm{C}_{\mathrm{o}}$ is the initial dye concentration in $\mathrm{mg} / \mathrm{L}$. $\mathrm{E}_{\mathrm{L}}$ value of 0.003 which is between 0 and 1 shows that the adsorption of Safranin $\mathrm{O}$ unto SMABT is favourable.

\section{Temkin isotherm}

Temkin isotherm is characterized by the uniform distribution of binding energy [Yang et al. 2011]. The linear form of the equation is given

$$
\begin{aligned}
& q_{e}=\frac{R T}{b} \ln A+\frac{R T}{b} \ln C_{e} \\
& B=\frac{R T}{b}
\end{aligned}
$$

Therefore, $\quad q_{e}=B \ln A+B \ln C_{e}$

The graph of $\mathrm{q}_{\mathrm{e}}$ against $\ln \mathrm{C}_{\mathrm{e}}$ in Fig. 10 shows a very good fit. The values of $\mathrm{A}$, Temkin isotherm equilibrium binding constant $\left(\mathrm{Lg}^{-1}\right)$, and $\mathrm{B}$, Temkin equilibrium constant which corresponds to the variation of adsorption energy $\left(\mathrm{kJmol}^{-1}\right)$, are shown in Table 2 .

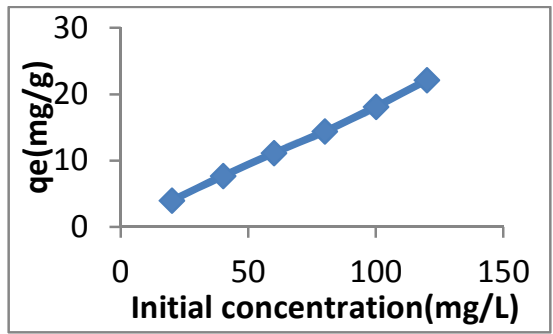

Fig.6 Effect of initial concentration on the adsorption of Safranin O on SMABT 


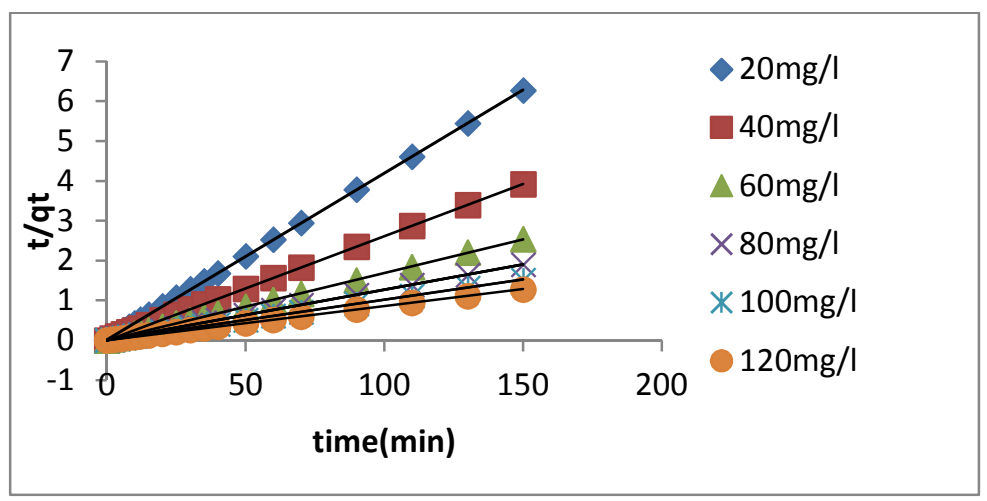

Fig.7 Pseudo second order kinetics for the adsorption of Safranin O on SMABT

Dubinin-Radushkevich (D-R) isotherm: The Dubinin-Radushkevich (D-R) isotherm is more inclusive than the Langmuir isotherm for it does not assume a homogenous surface or constant sorption potential (Carzon et al. 2012). It is used for the estimation of the characteristic porosity of the biomass as well as the mean free energy of adsorption. The equation is given by

$$
\ln q_{e}=\ln q_{x}-\beta\left[R T \ln \left(1+\frac{1}{C_{e}}\right)\right]^{2}
$$

where $q_{\mathrm{e}}$ is the amount of Safranin $\mathrm{O}$ adsorbed at equilibrium, $\beta$ is a constant related to the adsorption

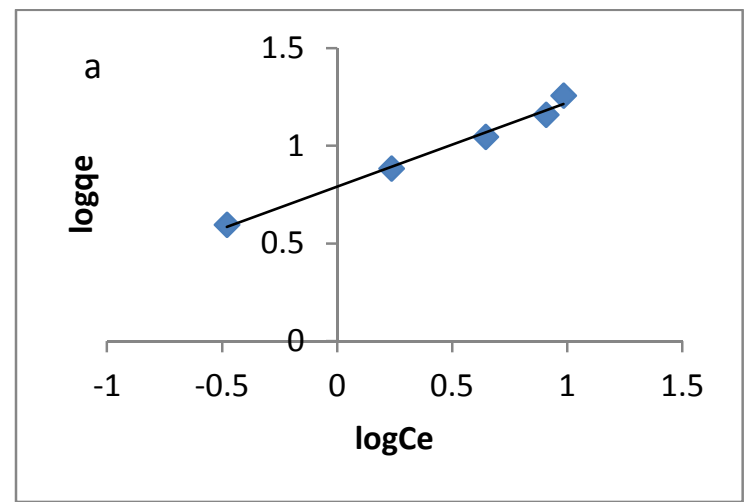

Fig. 8: Freundlich isotherm for the adsorption of Safranin O on modified African Border Tree energy, $q_{\mathrm{x}}$ is the maximum adsorption capacity, $\varepsilon$ is the Polanyi potential, that is equal to

$$
\varepsilon=R T \ln \left(1+\frac{1}{C_{e}}\right)
$$

The linear form of Eq. (10) is,

$\ln \mathrm{q}_{\mathrm{e}}=\ln \mathrm{q}_{\mathrm{x}}-\beta \varepsilon^{2}$

Table 2 gives the $\mathrm{R}^{2}$ value for the plot of $\mathrm{q}_{\mathrm{e}}$ against $\varepsilon^{2}$. The $q_{\mathrm{x}}$ and $\beta$ values in Table 2 were calculated from the slope and intercept of the plots (Fig. 11).

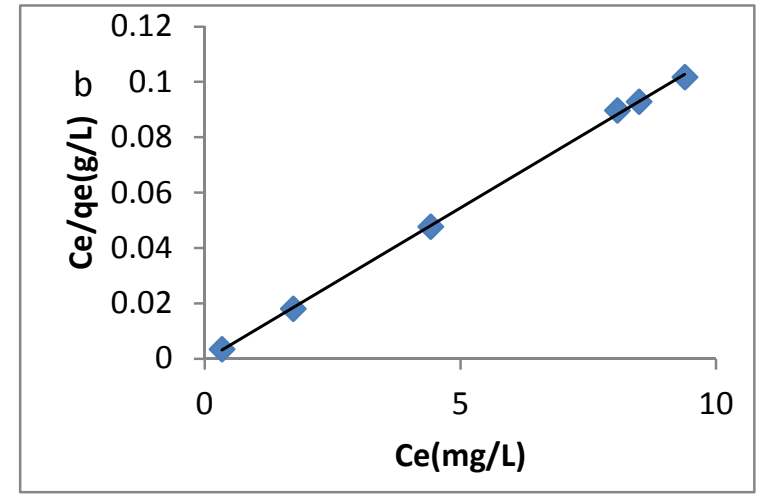

Fig. 9: Langmuir isotherms for the adsorption of Safranin $O$ on modified African Border Tree

Table 2: Freundlich, Langmuir, Temkin and Dubinin-Radushkevich Isotherms for the adsorption of Safranin O on modified African Border Tree

\begin{tabular}{lllc}
\hline Freundlich & Langmuir & Temkin & D-R \\
\hline $\mathrm{K}_{\mathrm{F}}=6.17$ & $\mathrm{~A}_{\mathrm{o}}=90.9 \mathrm{mg} / \mathrm{g}$ & $\mathrm{A}=8.84 \mathrm{mg} / \mathrm{g}$ & $\mathrm{q}_{\mathrm{x}}=2.86 \mathrm{mg} / \mathrm{g}$ \\
$\mathrm{n}=2.32$ & $\mathrm{~b}=18.3 \mathrm{~L} / \mathrm{mg}$ & $\mathrm{B}=793.6$ & $\beta=3.0 \times 10^{-4}$ \\
$\mathrm{R}^{2}=0.988$ & $\mathrm{R}^{2}=0.999$ & $\mathrm{R}^{2}=0.96$ & $\mathrm{E}=26.7 \mathrm{~kJ} / \mathrm{mol}$ \\
& $\mathrm{E}_{\mathrm{L}}=0.003$ & & $\mathrm{R}^{2}=0.788$ \\
\hline
\end{tabular}




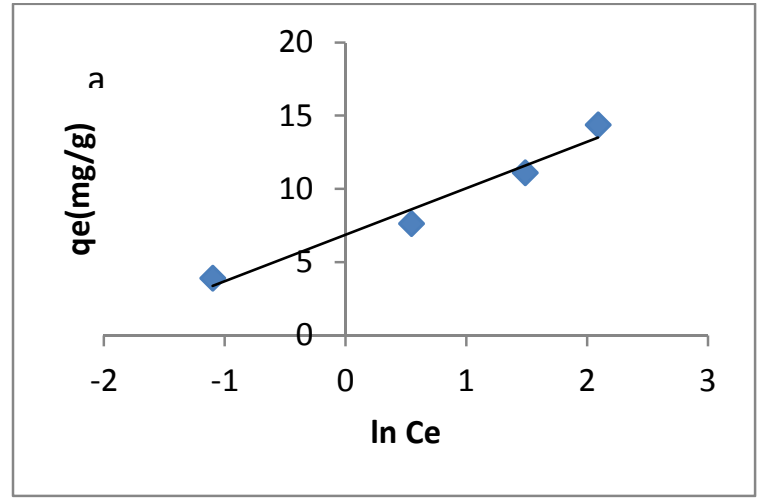

Fig. 10 Temkin isotherm for the adsorption of Safranin O

on SMABT

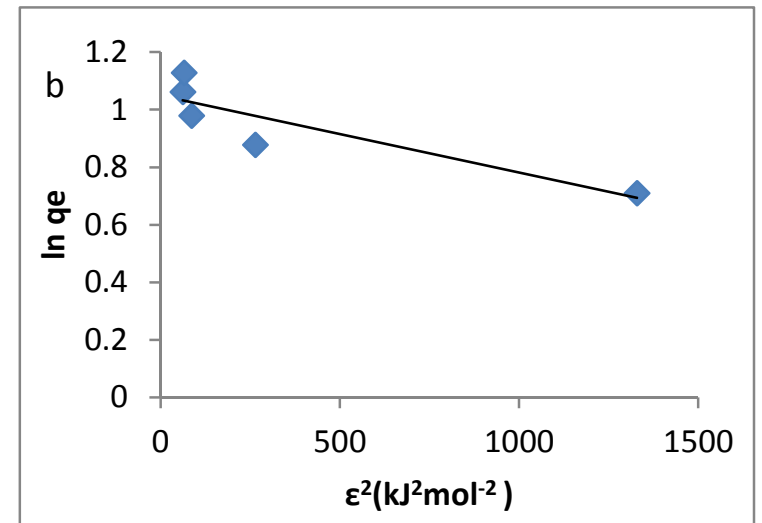

Fig. 11: Dubinin-Radushkevich (D-R) isotherm for the adsorption of Safranin O on SMABT

Table 3: Adsorption capacities of some adsorbents unto Safranin O dyes

\begin{tabular}{lll}
\hline Adsorbent(s) & Adsorption Capacity $(\mathrm{mg} / \mathrm{g})$ & Reference \\
\hline Alkali-treated Rice Husk & 9.77 & Chowdhury.et,al 2011 \\
Pretreated Rice Husk & 45.58 & Chowdhury.et.al 2011 \\
Alkali-treated Mango Seed & 31 & Maekbala.,et.al 2012 \\
Walnut shell & 40 & Zaghbani.,et.al 2008 \\
Guava leave & 47.62 & Ojedokun and Bello 2017 \\
NaOH-treated rice Husk & 37.97 & Chowdhury.et.al 2012 \\
Pineapple peels & 21.7 & Mohammad.,et.al 2014 \\
Senna alata & 23.8 & Ajaelu et al. 2017 \\
Sodium hydroxide modified & & \\
African Border Tree & $90.9 \mathrm{mg} / \mathrm{g}$ & This study \\
\hline
\end{tabular}

The mean free energy of biosorption, E, was obtained from the equation

$$
E=1 / \sqrt{2 \beta}
$$

The magnitude of $E$ value gives information about the biosorption mechanism as chemical ion-exchange or physical sorption. As reported by Atkins (2006), physisorption, is due to weak van der Waal forces between the adsorbent and the adsorbate. The magnitude of the energy of physisorption is in the region of less than $20 \mathrm{~kJ} / \mathrm{mol}$. Atkins further stated that covalent bond exist between the adsorbate and the adsorbent in chemisorption in which the substrate (adsorbent) is limited to monolayer coverage. The value of $\mathrm{E}$, the mean free energy of biosorption, obtained in this study as reflected in Table 3 was higher than $20 \mathrm{~kJ} / \mathrm{mol}$, and Langmuir isotherm (monolayer coverage) best fitted the surface coverage in this study. Similar result was obtained by Adebowale et al. (2014). The correlation factors of the four equilibrium models decreased as follows: Langmuir (0.999) $>$ Freundlich (0.988) > Temkin(0.96) $>$ D-R (0.76). Thus the D-R is not suitable for the description of the adsorption of Safranin O on SMABT. A comparison of the adsorption capacities of some adsorbents on Safranin $\mathrm{O}$ is presented in Table 3 . The Table showed that
SMABT was effective in the removal of Safranin O as compared to some other adsorbents.

Conclusion: The current study revealed that the chemically modified African Border Tree can be used as an adsorbent for the removal of Safranin $\mathrm{O}$ from waste water. The optimum operational $\mathrm{pH}$ was evaluated as 7. The amount of dye removed increased with increase in the initial concentration of the dye. Kinetic studies showed that pseudo second order was the best for describing the removal of Safranin O using SMABT. Langmuir isotherm also had the highest correlation factor, thus it was the best for describing the equilibrum process.

\section{REFERENCES}

Ahmad M. A, Ahmad, N and Bello O. S (2015). Removal of Remazol Brilliant Blue Reactive Dye from Aqueous Solutions Using Watermelon Rinds as Adsorbent. J. Disp. Sci. Technol. 36:845-858, 2015.

Ajaelu, C.J, Ibironke, L, Adedeji, V, Oladunni O (2011). Equilibrium and Kinetic Studies of the Biosorption of Heavy Metal (Cadmium) on Cassia siamea Bark. Am-Eur. J. Sci. Res. 6(3): 123-130. 
Ajaelu C. J, Atolaiye B, Ibironke L, Alao O. A. (2015). Kinetics, equilibrium and thermodynamics of heavy metal ion sequestration onto mango seed biomass (Mangifera indica). J. Chem. Pharmaceutical Res. 7 (605-617)

Ajaelu C.J, Dawodu M.O, Faboro E.O, Ayanda O.S(2017). Copper Biosorption by Untreated and Citric Acid Modified Senna alata Leaf Biomass in a Batch System: Kinetics, Equilibrium and Thermodynamics Studies. Physical Chemistry, 7(2): 31-41.

Atkins P, Paula J. (2006). The extent of adsorption. Atkin's Physical Chemistry. $8^{\text {th }}$ Ed. Pp 916918.

Bello O.S, Lasisi B.M, Adigun O. J, Ephraim V. (2017). Scavenging Rhodamin B dye using Moringer oleifera seed pod. Chem. Specn. and Bioavail. 29(1): 120-134.

Cazón, JP; Bernardelli, C; Viera, M; Donati, E; Guibal E (2012). Zinc and cadmium biosorption by untreated and calcium-treated Macrocystis pyrifera in a batch system. Bioresource Technology 116: 195-203.

Chowdury. S, Mishra. R, Kushwara. P, and Das P. (2011). Adsorption of dyes on activated carbons: influence of surface chemical groups. Biorem. J., $15,77-89$.

Chowdury. S, Mishra. R, Kushwara. P; Saha. P (2012). Colour removal from industrial effluents a comparative review of available technologies. AsiaPa4c. J-Chem Eng. 7: 236-29

Daru.U. (2005). Chromate removal from water using red mud and crossflow microfiltration, Desalination, 181,135-143.

Deshpande A.V, Kumar U. (2002). Effect of method of preparation on photophysical properties of $\mathrm{Rh} \mathrm{B}$ impregnated sol-gel host. J. Non-cryst. Solids. 306(2): 149-159.

Foletto, E.L.; Collazzo, G.C.; Mazutti, M.A.; Jahn, S.L. (2011) Adsorption of textile dye on zinc stannate oxide: Equilibrium, kinetic and thermodynamics studies. Sep. Sci. Technol., 46: 2510.

Ghanadzadeh A, Zanjanch M.A, Tribandpay R. (2002). The role of host environment on the aggregation properties of some ionic dye materials. J. Mol. Struct. 616: 167174.

Malekbala, M.R., Soltani, S.M., Yazdi, S.K. and Hosseini, S. (2012). Equilibrium and Kinetic Studies of Safranin Adsorption on Alkali-Treated Seed Integuments. International Journal of Chemical Engineering and Applications, 3, 160- 166.

Mohammed, M. A., Ibrahim, A., and Shitu, A (2014). Batch Removal of Hazardous Safranin-O in Wastewater Using Pineapple Peels as an Agricultural Waste Based Adsorbent. International Journal of Environmental Monitoring and Analysis. 2(3) : 28-133

Ojedokun, A.I, Bello O.S. (2016). Liquid phase adsorption of Congo red dye on functionalized corn cobs. Journal of Dipersion Sc. And Techn. 38(9): 1285-1294.

Ojo, T.A, Ojedokun A.I, Bello O.S. (2017). Functionalization of powdered walnut shell with orthophosphoric acid for Congo red dye removal. Particulate Science and Technology. 1-7.

Ojedokun A.T., Bello O. S. (2017a). Liquid phase adsorption of Congo red dye on functionalized corn cob. J. Dispersion Sci. Technol. 38(9): 1285-1294.

Ojedokun A.T., Bello O. S. (2017b). Kinetic modeling of liquid phase adsorption of Congo red dye using Guava seed based activated carbon. Appl. Wat. Sci.7: 19631977.

Vijayaraghavan, K. and Yun, Y.S. 2008. Bacterial biosorbents and biosorption. Biotechnol. Adv. 26, 266291.

Walsh, G.E., Bahnar, L.H. and Horning, W.B., 1980. Toxicity of textile mill effluents to freshwater and estuarine algae, crustaceans and fishes. Environ. Pollut. A21, 169-179.

Xiong, L; Yang, Y, Mai, J, Sun, W, Zhang C, Wei, D, Chen, Q, Ni, J. (2010). Adsorption behavior of methylene blue onto titanate nanotubes, Chem. Eng. J. 156: 313-320.

Yang Y, Jin D, Wang G, Liu D, Jia X, Zhao Y. (2011) Biosorption of Acid Blue 25 byunmodified and CPCmodified biomass of Penicillium YW01: Kinetic study, equilibrium isotherm and FTIR analysis. Colloids and Surfaces B: Biointerfaces 88: 521- 526.

Zafar M. N., Nadeem R., Hanif M. A. (2006). Biosorption of nickel from protonated rice bran. J. Harz. Mat. 143(1-2): 478-485

Zaghbani. N, Hafiane. A; Dhahbi. M (2008). Removal of Safranin $\mathrm{T}$ from wastewater using micellar enhanced ultrafiltration. Desalination, 348-356. 